\title{
Origin and Characteristics of Discharge at San Marcos Springs, South-Central Texas
}

Discharge from San Marcos Springs, the second largest spring complex in Texas, is used as a factor for enacting drought management strategies for the Edwards aquifer, although the hydrologic connection of the springs with this regional aquifer is not well understood.

Key Findings

- Discharge at San Marcos Springs is dominated by regional recharge sources and groundwater flow paths; the contribution to recharge from local streams is relatively minor.

- Different orifices of San Marcos Springs respond differently to changes in hydrologic conditions; Deep Spring is less responsive to changes in hydrologic conditions than are Diversion Spring and Weissmuller Spring.

- San Marcos Springs discharge is influenced by mixing with a component of saline groundwater.

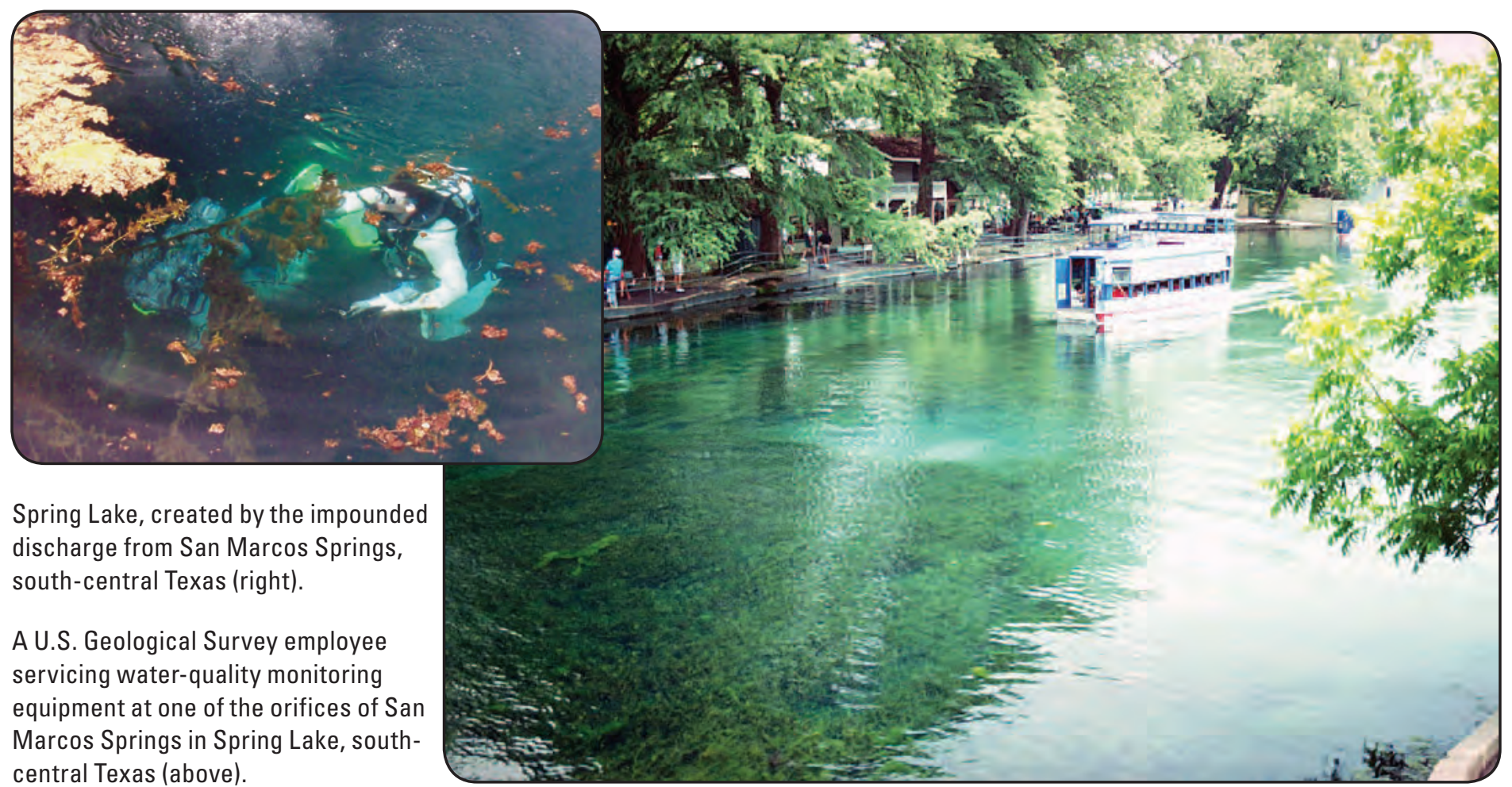

The Edwards aquifer in south-central Texas is one of the most productive aquifers in the Nation and is the primary source of water for the rapidly growing San Antonio area. Springs issuing from the Edwards aquifer provide habitat for several threatened and endangered species, serve as locations for recreational activities, and supply downstream users. Comal Springs and San Marcos Springs are major discharge points for the Edwards aquifer (fig. 1), and their discharges are used as thresholds in groundwater management strategies. Regional flow paths originating in the western part of the aquifer are generally understood to supply discharge at Comal Springs. In contrast, the hydrologic connection of San Marcos Springs with the regional Edwards aquifer flow system is less understood. During November 2008-December 2010, the U.S. Geological Survey, in cooperation with the San Antonio Water System, collected and analyzed hydrologic and geochemical data from springs, groundwater wells, and streams to gain a better understanding of the origin and characteristics of discharge at San Marcos Springs. 


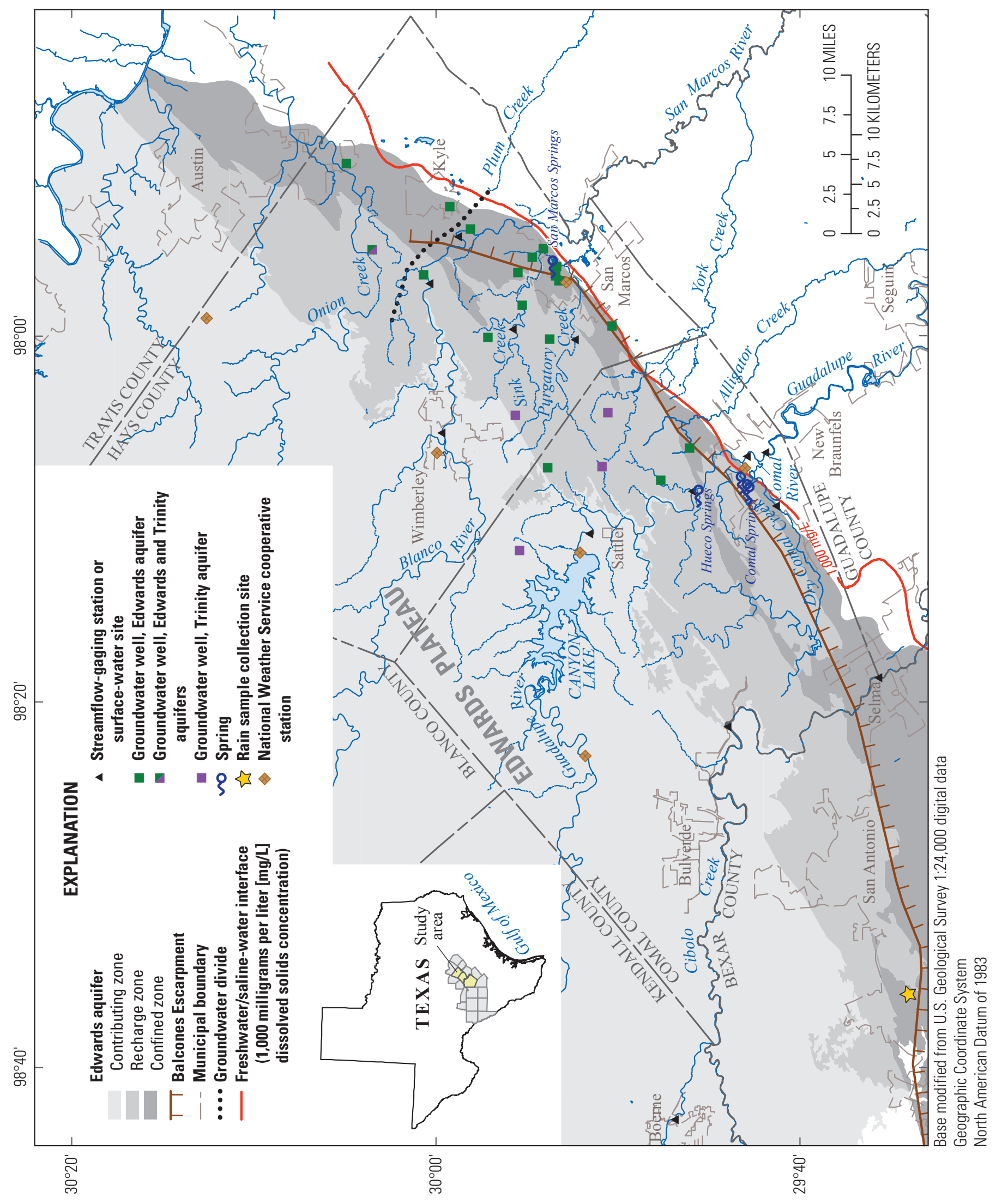

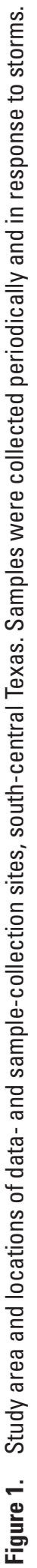




\section{A wide range of climatic and hydrologic conditions during the study allowed for investigation of controls on discharge at San Marcos Springs over much of its historical range of discharge.}

During the study, climatic and hydrologic conditions transitioned from exceptional drought to wetter than normal. Between November 1, 2008, and September 8, 2009, is referred to as the "dry period," and between September 9, 2009, and December 31, 2010, is referred to as the "wet period." The wide range of hydrologic conditions that occurred during this 25-month study - and corresponding changes in surface-water, groundwater and spring discharge, and in physicochemical properties and geochemistry — provides insight into the origin of the water discharging from San Marcos Springs. Three orifices at San Marcos Springs (Deep, Diversion, and Weissmuller Springs) were selected to be representative of larger springs at the spring complex (fig. 2). Potential sources of discharge at San Marcos Springs include (1) regional groundwater flow that has bypassed Comal Springs, (2) local recharge from nearby streams, (3) groundwater from the saline zone of the Edwards aquifer (downgradient of the freshwater/saline-water interface) (fig. 1), and (4) interaquifer flow from the underlying Trinity aquifer.
Previous studies have hypothesized that discharge at San Marcos Springs might include notable contributions of recharge from nearby streams, including the Guadalupe River, Cibolo Creek, Dry Comal Creek, Sink Creek, Purgatory Creek, York Creek, Alligator Creek, and, in particular, the Blanco River (Guyton and Associates, 1979; Ogden and others, 1986; Johnson and Schindel, 2008). Results from this study indicate that recharge from these local streams is not a major source of San Marcos Springs discharge.

Rather, discharge at San Marcos Springs is dominated by regional recharge sources and flow paths, even during wet hydrologic conditions when aquifer recharge is likely occurring from local streams. Geochemical modeling results using the program PHREEQC (Parkhurst and Appelo, 1999) indicate that the proportion of local stream recharge contributing to San Marcos Springs discharge increased from the dry period to the wet period, but even under wet conditions the proportion was less than 30 percent, and for most hydrologic conditions it was less than 10 percent (fig. 3).

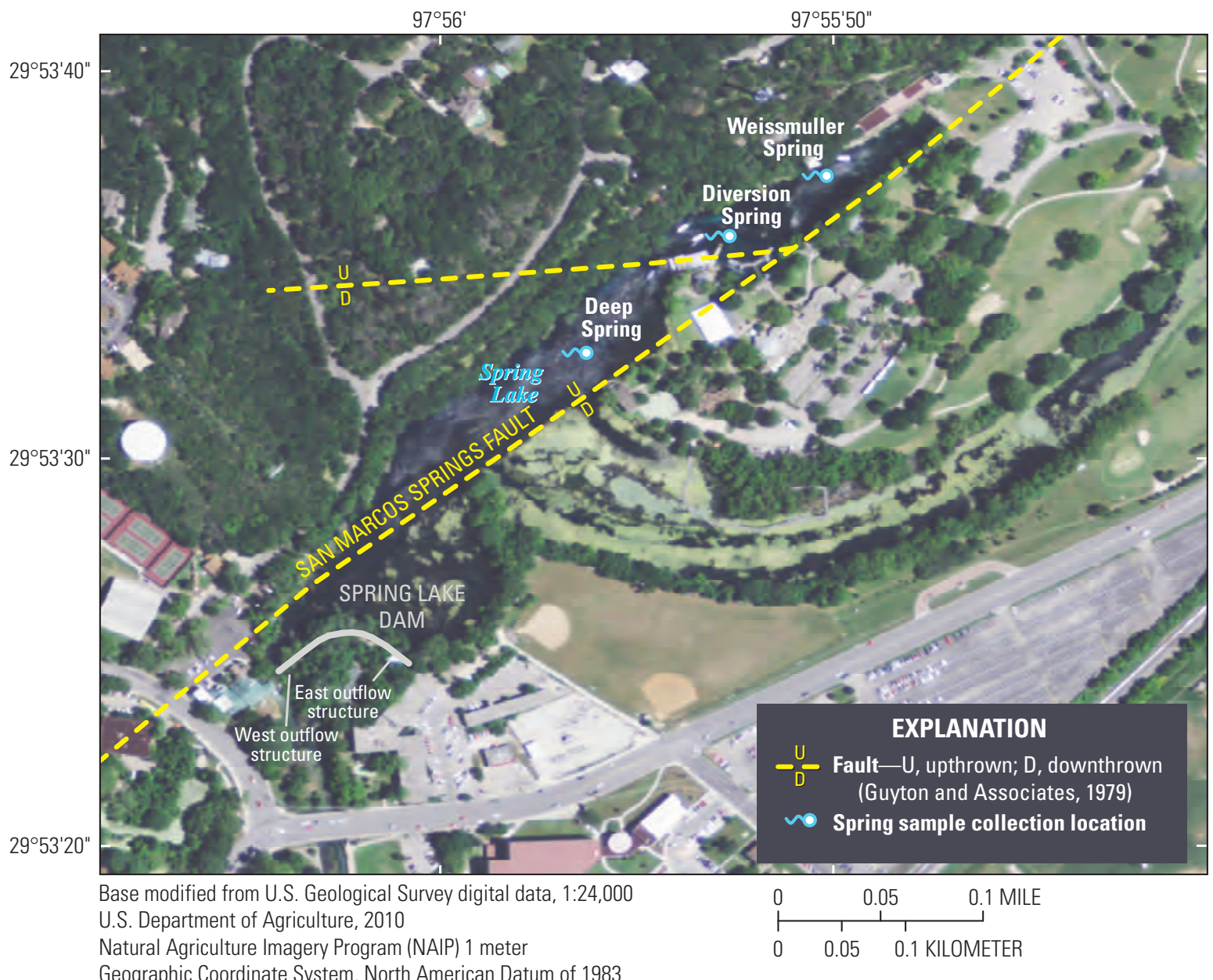

Figure 2. Spring Lake, San Marcos Springs complex, and location of sampled spring orifices. 


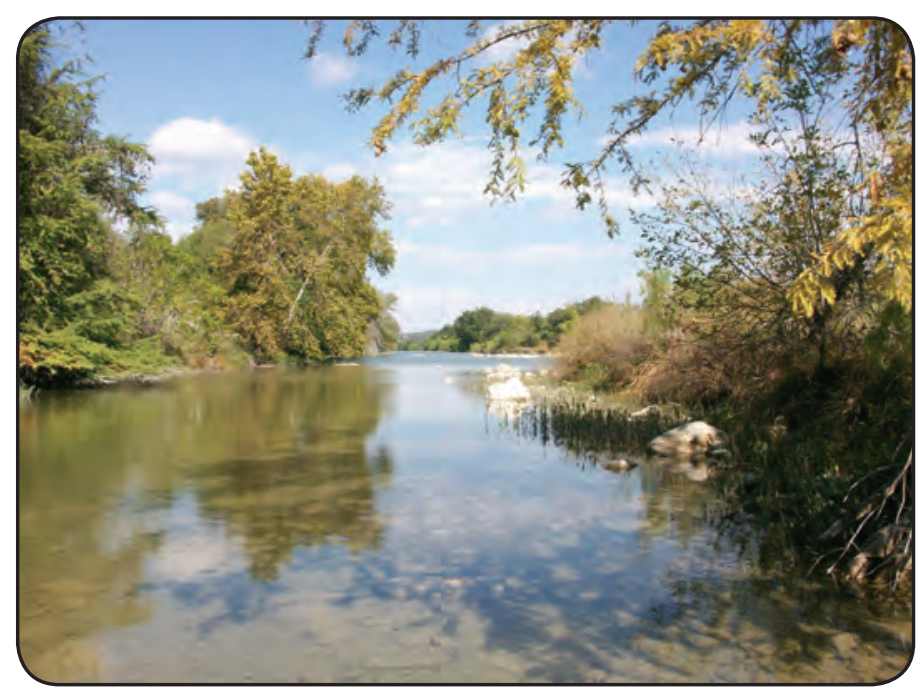

The Blanco River in Hays County, Texas.

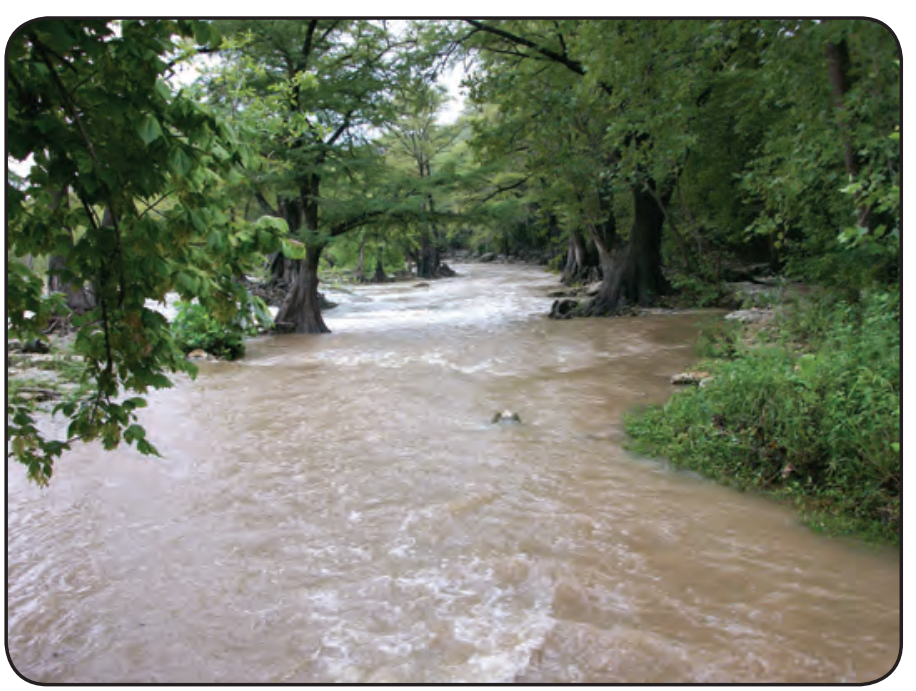

The Guadalupe River in Comal County, Texas.

\section{Geochemical modeling results indicate that the proportion of local stream recharge contributing to San Marcos Springs discharge was less than 10 percent for most hydrologic conditions.}

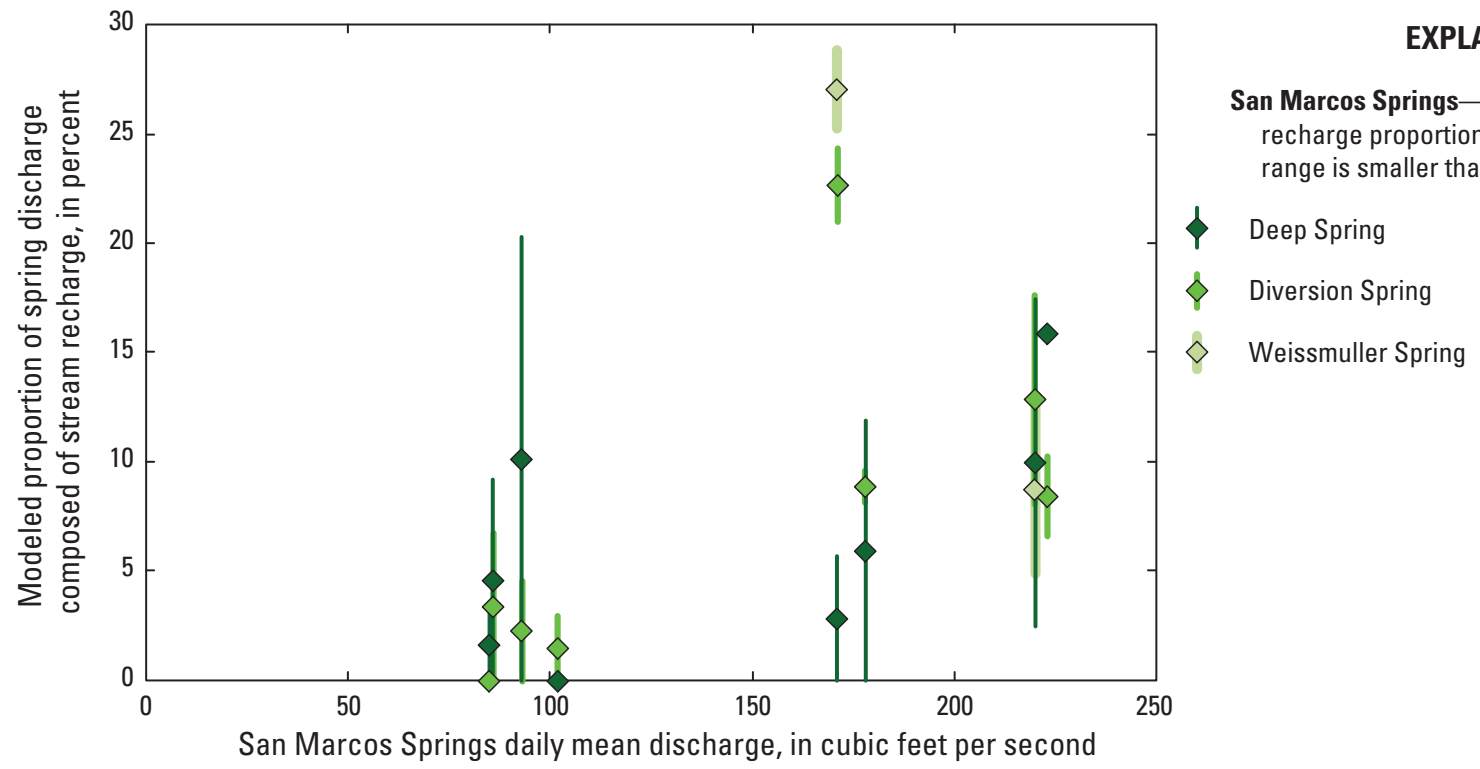

Figure 3. Relation between San Marcos Springs discharge and the modeled proportion of spring discharge composed of stream recharge from the Blanco River based on inverse geochemical modeling.

Geochemical modeling results also indicate that the effect of storm-related recharge from local focused recharge sources was small. For example, mixing models developed by using conservative tracers for the largest storm that occurred during the study, a named tropical storm (Hermine, September 7, 2010), indicate that recharge from the Blanco River composed less than 10 percent of discharge at San Marcos Springs immediately following the storm and for several months afterwards (fig. 4).
Modeling results for this and other storms indicate that San Marcos Springs was not notably affected by recharge events from local streams moving rapidly through transmissive flow paths. This hypothesis is also supported by a lack of marked changes in geochemistry from the dry period to the wet period in time-series data from wells located to the north of San Marcos Springs along possible flow paths from the Blanco River to the springs. 

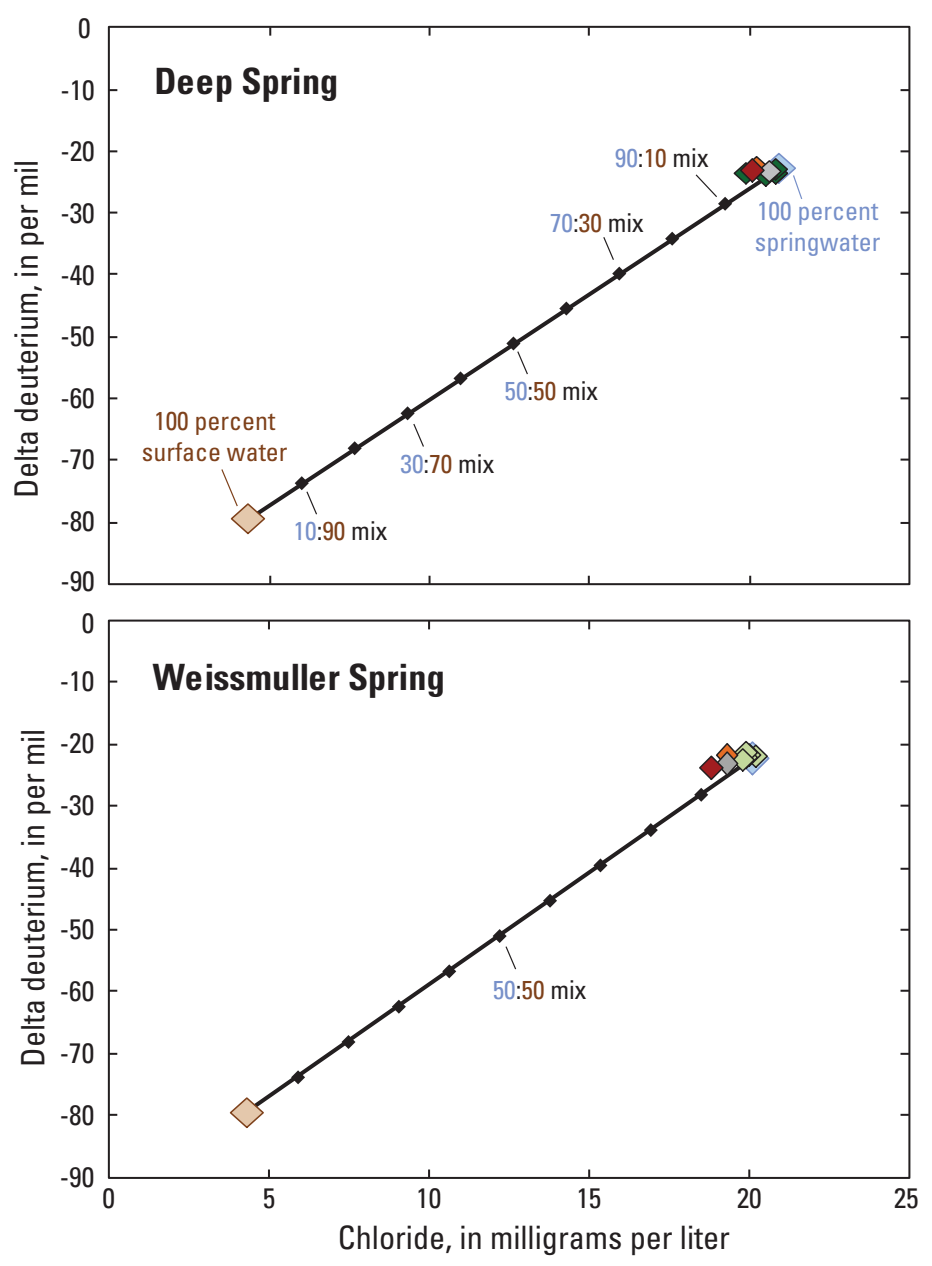

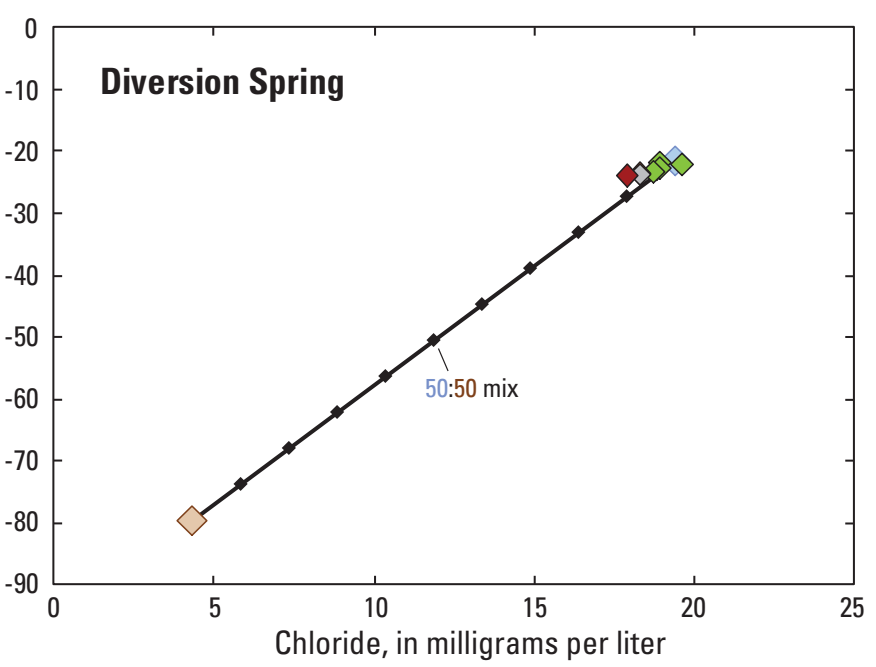

\section{EXPLANATION}

$\rightarrow$ Modeled mixing line - In 10 percent increments between springwater endmember (100 percent) and surface-water endmember (100 percent)

Mixing-model springwater endmemberPrestorm sample

Mixing-model surface-water endmemberStorm sample, Blanco River at Halifax Ranch near Kyle, Texas Sample collected in response to storm 3

- San Marcos Springs-Deep Spring

$\diamond \quad$ San Marcos Springs-Diversion Spring

$\diamond \quad$ San Marcos Springs-Weismuller Spring

Routine sample collected after storm 3, by date

September 29, 2010

October 29, 2010

December 1, 2010

Figure 4. Relation between chloride concentration and deuterium isotopes for two-component mixing models showing proportional mixing between surface-water (stream recharge) and springwater endmembers for San Marcos Springs samples collected immediately following and several months after Tropical Storm Hermine in September 2010.

\section{Different spring orifices at San Marcos Springs, Comal Springs, and Hueco Springs respond} differently to temporal changes in hydrologic conditions.

Differences in the geochemistry and variability of Comal Springs, Hueco Springs, and San Marcos Springs were compared to better understand flow paths and sources of spring discharge. Changes in hydrologic conditions that occurred at the beginning of the wet period resulted in large changes in discharge from the springs (fig. 5). At Hueco Springs, this change was accompanied by large changes in geochemistry in response to local rainfall and recharge events. At Comal Springs, changes in geochemistry were relatively minor as discharge increased, reflecting regional flow paths and discharge sources.

The geochemical response at San Marcos Springs as discharge increased was intermediate between Hueco and Comal Springs and was different for the different orifices (fig. 5). Deep Spring, similar to Comal Springs, was not responsive to changes in hydrologic conditions, which indicates that discharge at Deep Spring was likely dominated by regional and less variable flow paths. The geochemical response at Diversion Spring was more variable than at Deep Spring. Previous studies have also described differences between springs in the southern and northern parts of Spring Lake (Ogden and others, 1986). Diversion Spring was more affected by changes in recharge sources, but the nature of the geochemical changes, such as the increase in chloride concentration (fig. 5), indicates that increased discharge at Diversion Spring included an increased component of saline groundwater rather than recharge from local streams. At higher discharge, the composition of Diversion Spring became more like that of Deep Spring. Weissmuller Spring, which was sampled during only the wet period, had a composition and variability similar to Diversion Spring (fig. 5), indicating that these two springs were likely supplied by common flow paths. 
Discharge at San Marcos Springs is influenced by mixing with a component of saline groundwater.

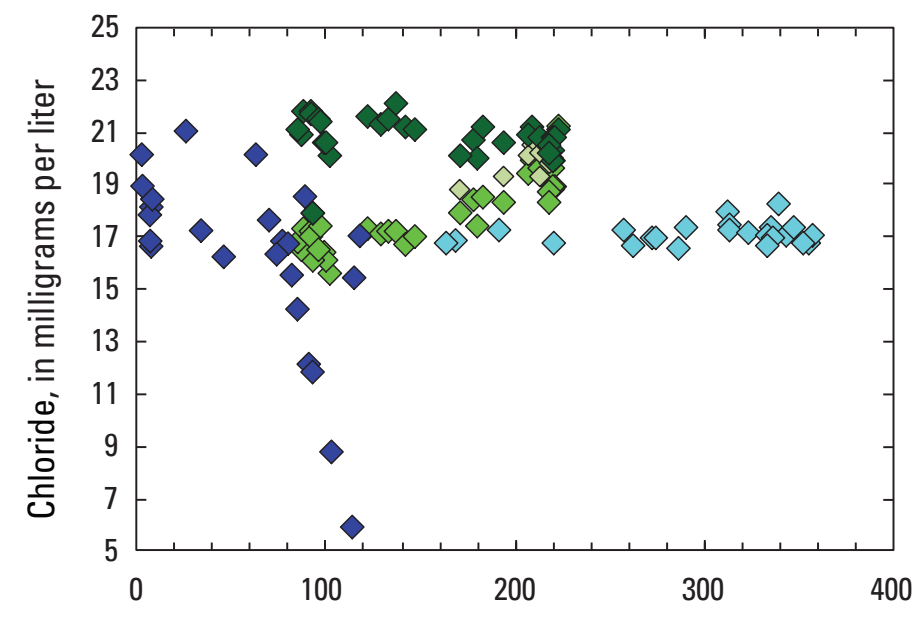

Spring daily mean discharge, in cubic feet per second

\section{EXPLANATION}

$\begin{array}{ll} & \text { Spring, by orifice } \\ \diamond & \text { San Marcos Springs (Deep Spring) } \\ \diamond & \text { San Marcos Springs (Diversion Spring) } \\ \diamond & \text { San Marcos Springs (Weissmuller Spring) } \\ \diamond & \text { Comal Springs (Spring 1) } \\ \diamond & \text { Hueco Springs (Spring A) }\end{array}$

Figure 5. Relation between spring discharge for Comal, Hueco, and San Marcos Springs and chloride concentration for samples collected from orifices of those springs.

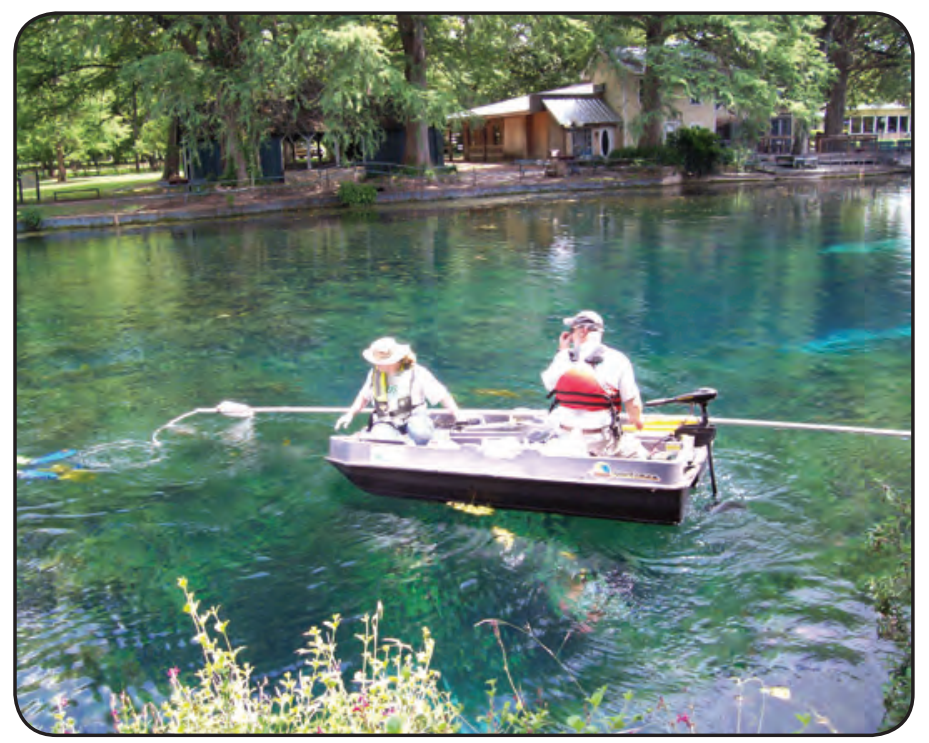

U.S. Geological Survey personnel and a diver from Texas State University above Weissmuller Spring, an orifice of San Marcos Springs in Spring Lake, south-central Texas.
Geochemical modeling results consistently indicate that, in addition to a dominant component of regional groundwater flow, a small contribution of saline water (more saline than the freshwater Edwards aquifer) is needed to account for the composition of San Marcos Springs. Both the Edwards aquifer saline zone and the underlying Trinity aquifer were considered as hydrologically plausible saline-water sources. Although the Trinity aquifer cannot be eliminated as a potential source, modeling results indicate that mixing with a small component (less than 1 percent) of saline-zone groundwater more likely accounts for the composition of San Marcos Springs discharge.

\section{This fact sheet is based on the following report:}

Musgrove, M., and Crow, C.L., 2012, Origin and characteristics of discharge at San Marcos Springs based on hydrologic and geochemical data (2008-10), Bexar, Comal, and Hays Counties, Texas: U.S. Geological Survey Scientific Investigations Report 2012-5126, 94 p., http://pubs.usgs.gov/ sir/2012/5126/.

\section{References}

Guyton, W.F., and Associates, 1979, Geohydrology of Comal, San Marcos, and Hueco Springs: Austin, Texas Department of Water Resources Report 234, 85 p.

Johnson, S.B., and Schindel, G.M., 2008, Evaluation of the option to designate a separate San Marcos pool for critical period management: San Antonio, Tex., Edwards Aquifer Authority, 109 p.

Ogden, A.E., Quick, R.A., Rothermel, S.R., and Lundsford, D.L., 1986, Hydrological and hydrochemical investigation of the Edwards aquifer in the San Marcos area, Hays County, Texas: San Marcos, Tex., Edwards Aquifer Research and Data Center, $364 \mathrm{p}$.

Parkhurst, D.L., and Appelo, C.A.J., 1999, User's guide to PHREEQC (v. 2)-A computer program for speciation, reaction-path, one-dimensional transport, and inverse geochemical calculations: U.S. Geological Survey WaterResources Investigations 99-4259, 312 p.

—By MaryLynn Musgrove and Cassi L. Crow

\section{For additional information contact:}

Director, Texas Water Science Center

U.S. Geological Survey

1505 Ferguson Lane

Austin, Texas 78754-4501

http://tx.usgs.gov/

Publishing support provided by Lafayette Publishing Service Center
ISSN 2327-6916 (print) ISSN 2327-6932 (online) http://dx.doi.org/10.3133/fs20133080 